\title{
Au-Loaded Titanium Dioxide Nanoparticles Synthesized by Modified Sol-Gel/Impregnation Methods and Their Application to Dye-Sensitized Solar Cells
}

\author{
Hathaithip Ninsonti, ${ }^{1,2}$ Weerasak Chomkitichai, ${ }^{2,3}$ Akira Baba, ${ }^{2}$ \\ Natda Wetchakun, ${ }^{4}$ Wiyong Kangwansupamonkon, ${ }^{5}$ Sukon Phanichphant, ${ }^{6}$ \\ Kazunari Shinbo, ${ }^{2}$ Keizo Kato, ${ }^{2}$ and Futao Kaneko ${ }^{2}$ \\ ${ }^{1}$ Department of Chemistry, Faculty of Science, Chiang Mai University, Chiang Mai 50200, Thailand \\ ${ }^{2}$ Center for Transdisciplinary Research, Niigata University, Niigata 910-2181, Japan \\ ${ }^{3}$ Department of Science, Faculty of Science and Technology, Uttaradit Rajabhat University, Uttaradit 53000, Thailand \\ ${ }^{4}$ Department of Physics and Materials Science, Faculty of Science, Chiang Mai University, Chiang Mai 50200, Thailand \\ ${ }^{5}$ National Nanotechnology Center, National Science and Technology Development Agency, Pathumthani 12120, Thailand \\ ${ }^{6}$ Materials Science Research Center, Faculty of Science, Chiang Mai University, Chiang Mai 50200, Thailand
}

Correspondence should be addressed to Sukon Phanichphant; sphanichphant@yahoo.com

Received 3 December 2013; Accepted 10 March 2014; Published 7 April 2014

Academic Editor: K. R. Justin Thomas

\begin{abstract}
Copyright (C) 2014 Hathaithip Ninsonti et al. This is an open access article distributed under the Creative Commons Attribution License, which permits unrestricted use, distribution, and reproduction in any medium, provided the original work is properly cited.

Au-loaded $\mathrm{TiO}_{2}$ nanoparticles were synthesized by the modified sol-gel method together with the impregnation method. Anatase phase of $\mathrm{TiO}_{2}$ was obtained in all samples with an average particle size of $20 \mathrm{~nm}$. For the enhancement of DSSCs, the dye-sensitized solar cells composed of the ITO/Au-loaded $\mathrm{TiO}_{2} / \mathrm{N}-719 /$ electrolyte/Pt were fabricated. Au-loaded $\mathrm{TiO}_{2}$ films were deposited by using squeegee method. Finally, the fabricated cells were studied upon an irradiation of solar light to study the performance. The fabricated cell with up to $1.0 \mathrm{~mol} \%$ Au-loaded $\mathrm{TiO}_{2}$ could enhance the performance by localized surface plasmon effect and scattering property.
\end{abstract}

\section{Introduction}

Recently, an increase in energy demand has led to significant progress in environmental remediation and renewable energy technologies such as photocatalytic oxidation, adsorption/separation processing, solar cells, fuel cells, and biofuels. One of the various renewable energy options, solar cell, stands out as the most ultimately sustainable choice in terms of its availability and huge potential. The solar cell for renewable energy options is applied through catalyst materials. Titanium dioxide $\left(\mathrm{TiO}_{2}\right)$ is one of the most efficient materials for dye-sensitized solar cells (DSSCs) due to its chemical stability, nontoxicity, good electrical properties, and inexpensiveness [1-4]. The phase structure of $\mathrm{TiO}_{2}$ exists in three polymorphs: anatase, rutile, and brookite. The anatase
$\mathrm{TiO}_{2}$ is used as dye-sensitized solar cells material because it has band gap energy of $3.2 \mathrm{eV}$ of which the absorption thresholds correspond to $380 \mathrm{~nm}$, suggesting that it is easy for photon-electron transfer under solar light irradiation [3]. At the present time many studies on dye-sensitized solar cells (DSSCs) have been reported due to their high efficiency property and low cost of materials [1-4].

In the active layer of DSSCs, a monolayer of organic dye molecules covered with covalent bond on anatase $\mathrm{TiO}_{2}$ film is generally used [5]. When the metal nanoparticles are incorporated in $\mathrm{TiO}_{2}$ film of DSSCs, localized surface plasmon or light scattering can enhance the electric field on the active dye layer which can increase the light absorption [6-8]. Moreover, metal nanoparticles can perform as an electron acceptor from the photo-excited semiconductors. 
Therefore, the electron transfer rate could be improved and the increase of photocurrent was obtained [6,9]. Au has several advantages such as high conductivity and chemical and thermal stability [10]. For these reasons, Au nanoparticles were chosen to induce light scattering and localized surface plasmon excitation for the improvement of DSSCs performance.

There are many ways to synthesize $\mathrm{TiO}_{2}$ such as precipitation method [11-13], solvothermal method [14-17], solgel method [18-22], spray pyrolysis [23-26], and microwave method [27-29]. Sol-gel process consists of 2 main reactions, hydrolysis and condensation [18-22, 30-33]. In our previous work, we reported the preparation of $\mathrm{TiO}_{2}$ by the modified sol-gel method using cellophane membrane to decrease the diffusion rates of reactants in hydrolysis and condensation steps. This synthesis method had many advantages such as good reproducibility, good ability to obtain $\mathrm{TiO}_{2}$ in nanosized scale, and good production for high purity products [30, 31].

In this research, $\mathrm{TiO}_{2}$ and $\mathrm{Au}$-loaded $\mathrm{TiO}_{2}$ nanoparticles were synthesized by the modified sol-gel method and coupling the modified sol-gel with impregnation methods, respectively. The as-prepared samples were characterized by X-ray diffractometry, scanning electron microscopy, transmission electron microscopy, energy dispersive $\mathrm{X}$ ray spectrophotometry, and Brunauer-Emmett-Teller techniques. The obtained particles were used to enhance DSSCs performance.

\section{Experimental}

2.1. Preparation of $\mathrm{TiO}_{2}$ Nanoparticles. Titanium dioxide $\left(\mathrm{TiO}_{2}\right)$ nanoparticles were synthesized by the modified sol-gel method [30, 31]. Titanium tetraisopropoxide (Ti $\left[\mathrm{OCH}\left(\mathrm{CH}_{3}\right)_{2}\right]_{4}$ (TTIP), Aldrich, England), absolute ethanol $\left(\mathrm{C}_{2} \mathrm{H}_{5} \mathrm{OH}\right.$, Merck, Germany), and ammonia $\left(\mathrm{NH}_{3}\right.$, Merck, Germany) were used as the starting materials for synthesizing $\mathrm{TiO}_{2}$ nanoparticles. Titanium tetraisopropoxide $(20 \mathrm{~mL})$ was dissolved in $250 \mathrm{~mL}$ absolute ethanol and mixed until a homogeneous solution was obtained. The mixture of TTIP and absolute ethanol was loaded into a cellophane membrane and suspended for $1 \mathrm{~h}$ in a clear solution containing 1:1 ratio of ethanol (95\%) and deionized water and $7 \mathrm{~mL}$ of ammonia solution (25\%) as shown in Figure 1. After the completion of the dialysis process, the suspension was centrifuged at $7500 \mathrm{rpm}$ for $10 \mathrm{~min}$, washed with deionized water, and then dried in an oven at $60^{\circ} \mathrm{C}$ for $24 \mathrm{~h}$. The white powders were then calcined in a furnace at a temperature of $400^{\circ} \mathrm{C}$ for $3 \mathrm{~h}$.

2.2. Preparation of Au-Loaded $\mathrm{TiO}_{2}$ Nanoparticles. The nominal $0.50-3.0 \mathrm{~mol} \% \mathrm{Au}$-loaded $\mathrm{TiO}_{2}$ powders were prepared by the impregnation method. The appropriate amounts of gold (III) chloride hydrate $\left(\left(\mathrm{H}\left(\mathrm{AuCl}_{4}\right) \cdot \mathrm{H}_{2} \mathrm{O}\right.\right.$, Electron Microscopy Science) solution were added in $\mathrm{TiO}_{2}$ nanoparticles as described previously in Section 2.1. Then, the asprepared samples were mixed until being homogeneous. Finally, the obtained powders were dried at $60^{\circ} \mathrm{C}$ for $24 \mathrm{~h}$ and calcined at $400^{\circ} \mathrm{C}$ for $3 \mathrm{~h}$.

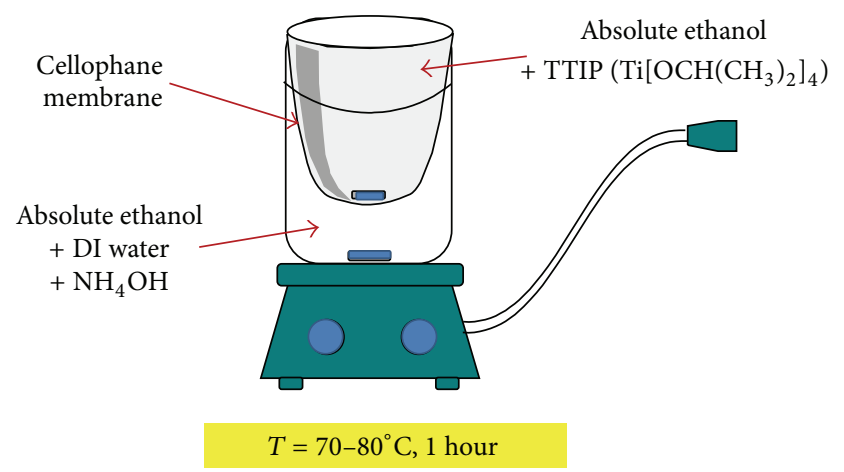

FIGURE 1: Scheme of the modified sol-gel method.

2.3. Characterization of $\mathrm{TiO}_{2}$ and $\mathrm{Au}$-Loaded $\mathrm{TiO}_{2}$ Nanoparticles. The crystal structure and crystallinity of $\mathrm{TiO}_{2}$ and Au-loaded $\mathrm{TiO}_{2}$ nanoparticles were examined by X-ray diffractometry (JDX-3530, JEOL, Japan) using the Ni-filtered monochromatic with $\mathrm{CuK}_{\alpha}$ radiation. The detection range was $15-75^{\circ}$ with the step size of $0.10^{\circ}\left(2 \theta^{\circ} / \mathrm{s}\right)$. Morphologies and particle sizes of $\mathrm{TiO}_{2}$ and $\mathrm{Au}$-loaded $\mathrm{TiO}_{2}$ nanoparticles were investigated by scanning electron microscopy (SEM, JSM5410-LV, JEOL, Japan) and transmission electron microscopy (TEM, JEM-2010, JEOL, Japan). The chemical composition of $\mathrm{TiO}_{2}$ and $\mathrm{Au}$-loaded $\mathrm{TiO}_{2}$ nanoparticles was examined by energy dispersive X-ray spectrophotometry (EDXS, ISIS300, Oxford, England). Specific surface area $\left(\mathrm{SSA}_{\mathrm{BET}}\right)$ of the samples was investigated by the BrunauerEmmett-Teller (BET, Micromeritics Tristar 3000). An average particle diameter $\left(d_{\mathrm{BET}}\right)$ of $\mathrm{TiO}_{2}$ and Au-loaded $\mathrm{TiO}_{2}$ nanoparticles was calculated using the following formula: $d_{\mathrm{BET}}=6 /\left[\left(\rho_{\mathrm{TiO} 2} \times \mathrm{SSA}_{\mathrm{BET}} \times\right.\right.$ wt. $\left.\% \mathrm{TiO}_{2}\right)+\left(\rho_{\mathrm{Au}} \times \mathrm{SSA}_{\mathrm{BET}} \times\right.$ wt. $\% \mathrm{Au})]$, where $\rho_{\mathrm{TiO} 2}$ and $\rho_{\mathrm{Au}}$ are the weight densities of $\mathrm{TiO}_{2}\left(3.84 \mathrm{~g} \mathrm{~cm}^{-3}\right)$ and $\mathrm{Au}\left(19.30 \mathrm{~g} \mathrm{~cm}^{-3}\right)$, respectively.

2.4. Fabrication of DSSCs. DSSCs were fabricated by $\mathrm{TiO}_{2}$ and $\mathrm{Au}$-loaded $\mathrm{TiO}_{2}$ nanoparticles for comparison of the efficiency performance. ITO glass substrate with a sheet resistance of $10 \Omega / \mathrm{sq}$ was used as an anode. Dish washing liquid solution, water, distilled water, and DI water were used for cleaning of ITO substrate. After cleaning process, squeegee technique was used to deposit $\mathrm{TiO}_{2}$ or Au-loaded $\mathrm{TiO}_{2}$ layers as follows: $\mathrm{TiO}_{2}$ or Au-loaded $\mathrm{TiO}_{2}$ nanoparticles were dispersed in ethanol with the concentration of 2, 3, 4 , or $5 \mathrm{M}$ in order to optimize the appropriate thickness. Then, $\mathrm{TiO}_{2}$ or Au-loaded $\mathrm{TiO}_{2}$ pastes were coated on ITO substrates by squeegee technique. $\mathrm{TiO}_{2}$ or Au-loaded $\mathrm{TiO}_{2}$ films were then calcined at $450^{\circ} \mathrm{C}$ for $90 \mathrm{~min}$. To prevent the corrosion of $\mathrm{Au}$ particles by iodine electrolyte, Au-loaded $\mathrm{TiO}_{2}$ films were immersed in $0.001 \mathrm{M}$ 1-octadecanethiol $\left(\mathrm{CH}_{3}\left(\mathrm{CH}_{2}\right)_{17} \mathrm{SH}\right.$, Aldrich, England) for $15 \mathrm{~h}$ after calcination step. N-719 (di-tetrabutylammonium cis-bis (isothiocyanato) bis $\left(2,2^{\prime}\right.$-bipyridyl- $4,4^{\prime}$-dicarboxylato) ruthenium (II), Sigma-Aldrich) was used as a photosensitized dye. $\mathrm{TiO}_{2}$ or Au-loaded $\mathrm{TiO}_{2}$ films were immersed in $0.5 \mathrm{mM} \mathrm{N}-719$ dye for $12 \mathrm{~h}$. DSSCs were fabricated as shown in Figure 2. 


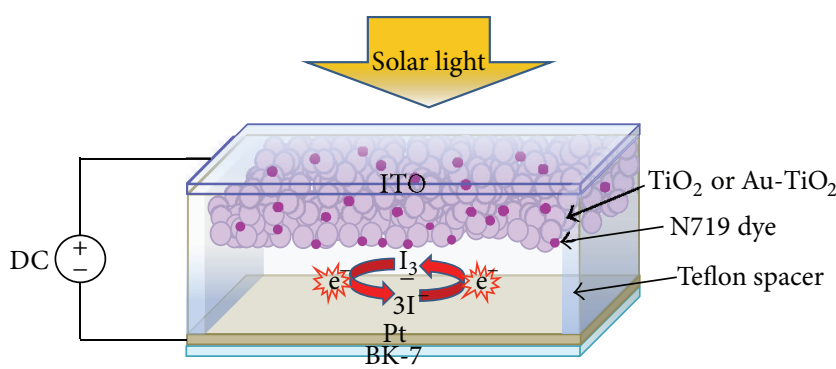

FIgURE 2: Scheme of fabricated dye-sensitized solar cells (DSSCs).

0.1 M LiI, 0.05 $\mathrm{M} \mathrm{I}_{2}, 0.6 \mathrm{M} \mathrm{tBP}$, and $0.5 \mathrm{M}$ tetrabutylammonium iodide in acetonitrile were used as electrolyte (for the optimization of the appropriate thickness, only $0.1 \mathrm{M} \mathrm{LiI}$ and $0.05 \mathrm{M} \mathrm{I}_{2}$ in acetonitrile were used as electrolyte). Pt film prepared by vacuum evaporation technique was used as the cathode.

2.5. Characterization of the Fabricated DSSCs. The absorption of $\mathrm{TiO}_{2}$ and Au-loaded $\mathrm{TiO}_{2}$ films was observed by UV-vis spectroscopy technique (UV-vis spectrometer, V-650, JASCO). Photovoltaic properties were studied by irradiating a solar simulator (HAL-C100, $100 \mathrm{~W}$ compact xenon light source, ASAHI SPECTRA) to the fabricated DSSCs.

\section{Results and Discussion}

3.1. Synthesis and Characterization of Au-Loaded $\mathrm{TiO}_{2} \mathrm{Nano}-$ particles. In this research, the $\mathrm{TiO}_{2}$ and Au-loaded $\mathrm{TiO}_{2}$ nanoparticles were prepared by the modified sol-gel method and the modified sol-gel method together with the impregnation method, respectively. The preparation of the $\mathrm{TiO}_{2}$ was followed from our previously reported research [30, 31]. The sol-gel method consists of hydrolysis and condensation of titanium alkoxides, $\mathrm{Ti}(\mathrm{OR})_{n}$, to form oxopolymers, which are converted to an oxide complex as equation mentioned in our previous report [30].

The rates of hydrolysis and condensation are important factors that might affect characteristic of Au-loaded $\mathrm{TiO}_{2}$. Smaller particle sizes were obtained from hydrolysis and condensation rates which are controlled by basic solution [34-37]. Consequently, cellophane membrane was used to control the hydrolysis and condensation rates in the reaction to acquire the nanosized particles [30, 31]. Moreover, $\mathrm{TiO}_{2}$ loading with $\mathrm{Au}$ was produced by the impregnation method which is a very simple technique and does not require expensive equipment. The homogeneous powders of $\mathrm{TiO}_{2}$ show white color, while increase of Au ions changed the color to grayish purple.

The structure confirmation of $\mathrm{TiO}_{2}$ and Au-loaded $\mathrm{TiO}_{2}$ nanoparticles was obtained by comparison with the Joint Committee on Powder Diffraction Standards (JCPDS) Card Files numbers 21-1272 and 04-0784. Figure 3 shows the XRD patterns of the $\mathrm{TiO}_{2}$ and $1.0 \mathrm{~mol} \% \mathrm{Au}$-loaded $\mathrm{TiO}_{2}$ nanoparticles. The results of the $\mathrm{TiO}_{2}$ and $1.0 \mathrm{~mol} \%$ Au-loaded $\mathrm{TiO}_{2}$ nanoparticles confirmed anatase structures according

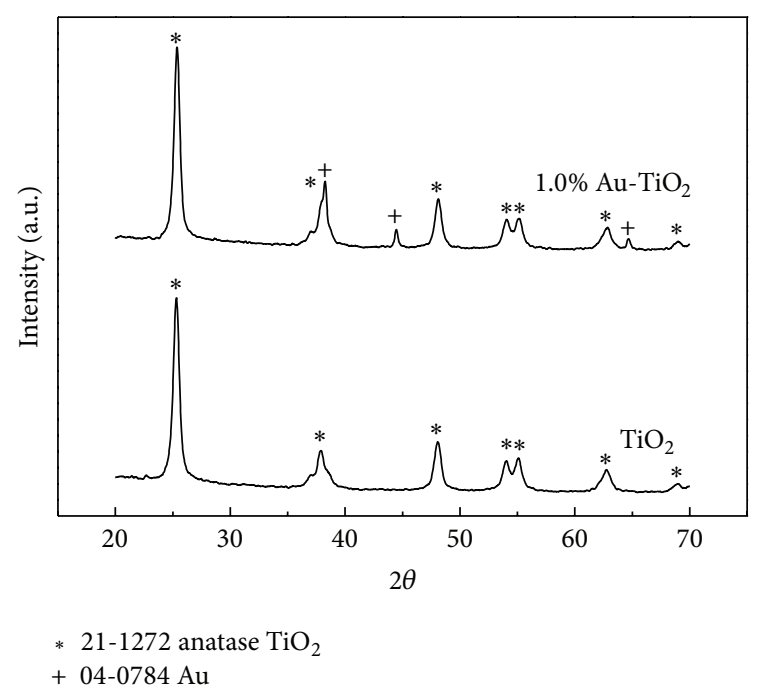

Figure 3: XRD patterns of the $\mathrm{TiO}_{2}$ and $1.0 \mathrm{~mol} \%$ Au-loaded $\mathrm{TiO}_{2}$ nanoparticles.

to JCPDS file number 21-1272 [30, 31]. The Au-loading might not affect the phase of $\mathrm{TiO}_{2}$ nanoparticles. The diffraction peaks of $\mathrm{Au}$ were found on $\mathrm{Au}$-loaded $\mathrm{TiO}_{2}$ nanoparticles at $2 \theta$ value of $38.2^{\circ}$ and $44.4^{\circ}$ according to JCPDS file number 04-0784. The high intensity value of the XRD peaks shows that all of the samples have well crystalline structure and the broad peaks at $2 \theta$ value of $25.2^{\circ}$ show that the particles have a small average crystallite size.

The specific surface area $\left(\mathrm{SSA}_{\mathrm{BET}}\right)$ of the $\mathrm{TiO}_{2}$ and $\mathrm{Au}-$ loaded $\mathrm{TiO}_{2}$ nanoparticles was found to be in the range of $69-109 \mathrm{~m}^{2} \mathrm{~g}^{-1}$ with the particle diameter in the range of $14-21 \mathrm{~nm}$, corresponding well with the XRD results. It was reported that high surface area of $\mathrm{TiO}_{2}$ active layer has many advantages such as large amount of dye adsorption, high light-harvesting efficiency, rapid electron transport, and low electron recombination [38-40]. Therefore, high photoefficiency could be expected.

Morphologies, particle sizes, and element chemical compositions were investigated by scanning electron microscopy (SEM) as shown in Figure 4(a). The SEM result shows the rough morphology and the presence of agglomerated nanoparticles with an average diameter of 50-100 nm. From the EDS spectra as shown in Figure 4(e), the chemical compositions of 1.0 mol\% Au-loaded $\mathrm{TiO}_{2}$ showed the characteristic X-ray energy level of titanium, oxygen. The characteristic peaks of Au were observed to confirm the presence of $\mathrm{Au}$ corresponding to the XRD results. Furthermore, element composition of Au-loaded $\mathrm{TiO}_{2}$ was investigated by EDS mapping mode. Figures 4(b), 4(c), and 4(d) show element composition of $\mathrm{Ti}, \mathrm{O}$, and $\mathrm{Au}$ in $1.0 \mathrm{~mol} \% \mathrm{Au}-$ loaded $\mathrm{TiO}_{2}$ nanoparticles. The presence of $\mathrm{Au}$ in the sample was confirmed. Further analysis for the accurate sizes and morphology of the nanoparticles was carried out by TEM observation. The average particle diameter of $\mathrm{TiO}_{2}$ and $\mathrm{Au}-$ loaded $\mathrm{TiO}_{2}$ nanoparticles was in the range of $15-20 \mathrm{~nm}$ as shown in Figure 5. 
Ti Kal

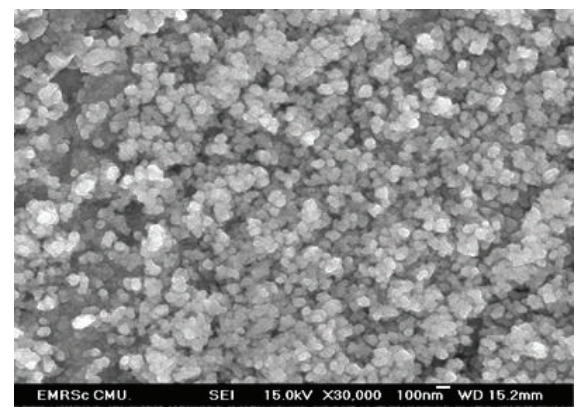

(a)

O Ka1

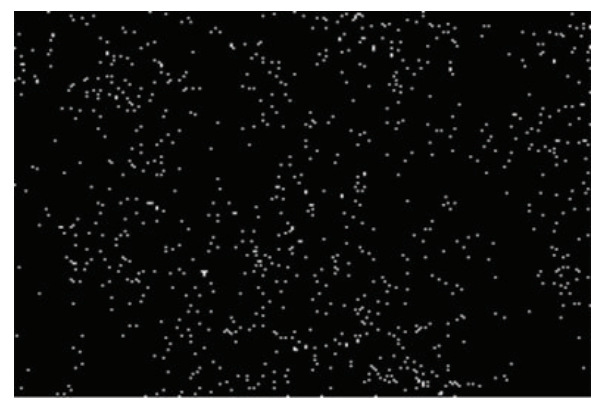

(c)

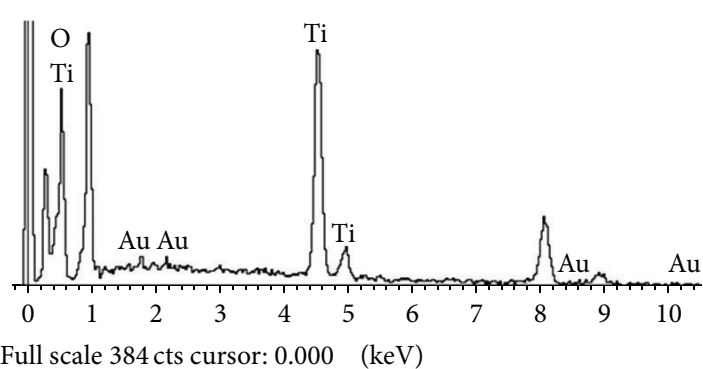

(e)

Full scale 384 cts cursor: $0.000 \quad$ (keV)

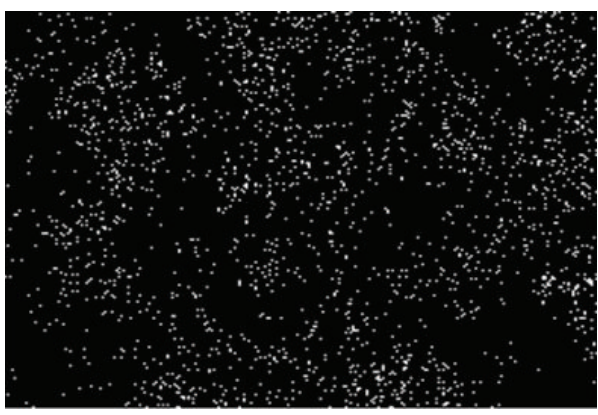

(b)

Au La1

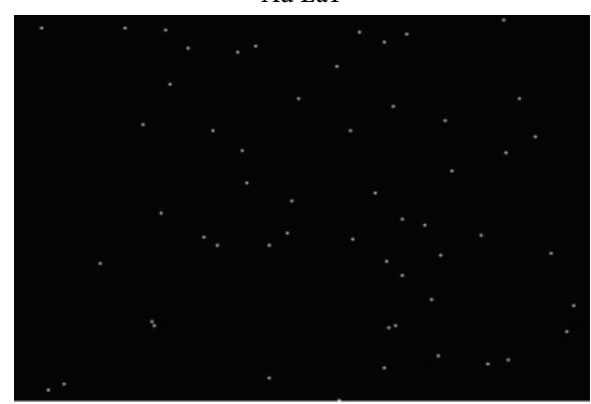

(d)

Figure 4: (a) SEM micrographs and EDS mapping mode of (b) $\mathrm{Ti}$, (c) O, (d) Au, and (e) EDS spectra of 1.0 mol\% Au-loaded TiO 2 nanoparticles.

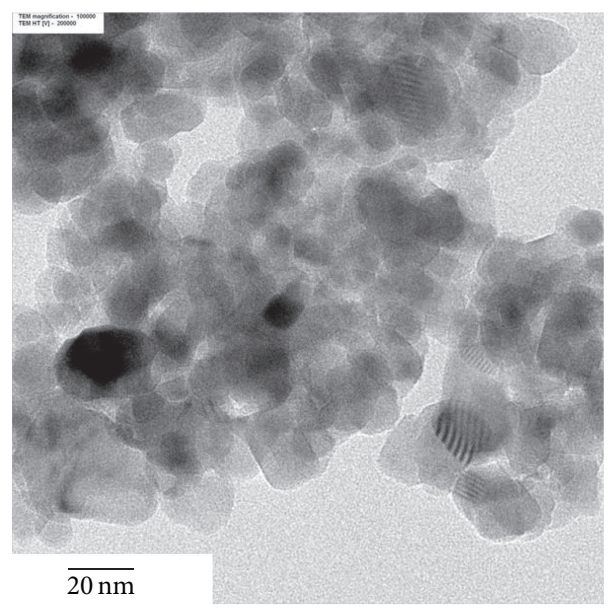

FIgURE 5: TEM micrograph of $1.0 \mathrm{~mol} \%$ Au-loaded $\mathrm{TiO}_{2}$ nanoparticles. 


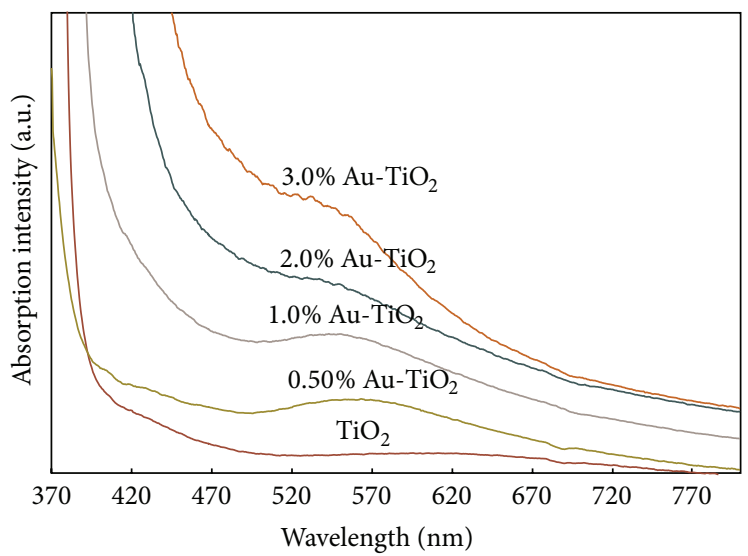

FIgURE 6: UV-vis absorption spectra of $\mathrm{TiO}_{2}$ and 0.50-3.0 mol\% Au-loaded $\mathrm{TiO}_{2}$ films deposited on $\mathrm{ITO}$ substrate.

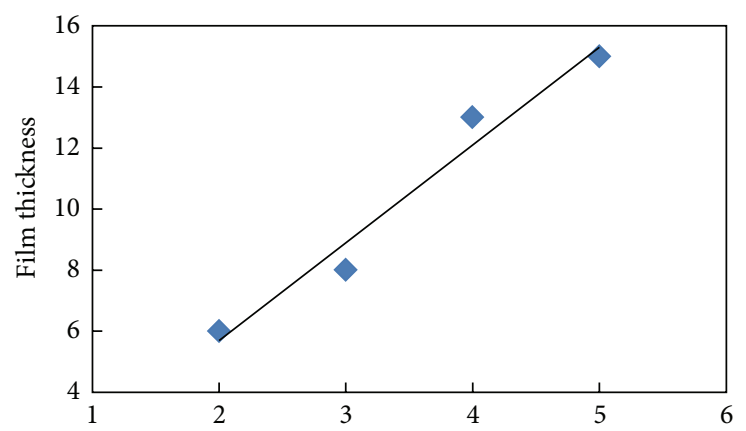

Molar concentration of $3.0 \mathrm{~mol} \%$ Au-loaded $\mathrm{TiO}_{2}$ paste (M)

(a)

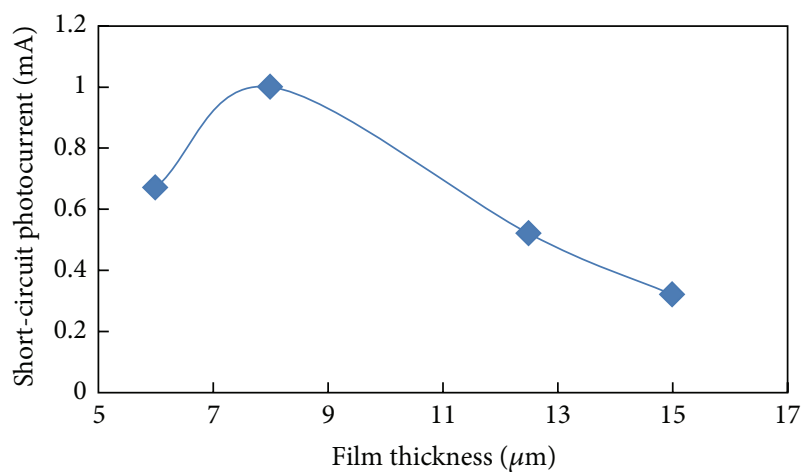

(b)

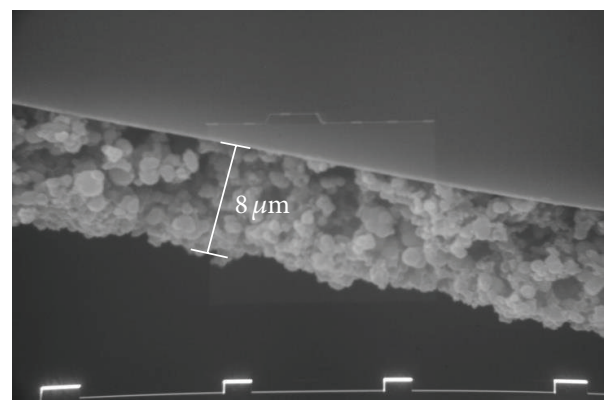

(c)

FIgURE 7: (a) Molar concentration of $\mathrm{TiO}_{2}$ paste versus film thickness of $3.0 \mathrm{~mol} \% \mathrm{Au}-\mathrm{TiO}_{2}$ film. (b) Film thickness versus short-circuit photocurrent of $3.0 \mathrm{~mol} \% \mathrm{Au}_{-} \mathrm{TiO}_{2}$ film. (c) SEM image of $3.0 \mathrm{~mol} \% \mathrm{Au}-\mathrm{TiO}_{2}$ film prepared by squeegee method with using $3 \mathrm{M}^{\mathrm{TiO}} \mathrm{O}_{2}$ paste.

3.2. Characterization and Optimization of Au-Loaded $\mathrm{TiO}_{2}$ Films. Figure 6 shows the UV-vis absorption spectra of $\mathrm{TiO}_{2}$ and $0.50-3.0 \mathrm{~mol} \%$ Au-loaded $\mathrm{TiO}_{2}$ films deposited on ITO substrate. A broad peak of $\mathrm{Au}$ appeared in the wavelength of $530-580 \mathrm{~nm}$ and increased intensity with increasing the $\mathrm{Au}$ loading amount on the $\mathrm{TiO}_{2}$ nanoparticles. This result indicated that the localized surface plasmon resonance could be excited on Au-loaded $\mathrm{TiO}_{2}$ nanoparticles [41]. As mentioned in the previously reported research by many groups, the film thickness is one of the most important factor effects on the performance of DSSCs [42, 43]. The film thickness was optimized by varying the concentration of $3.0 \mathrm{~mol} \% \mathrm{Au}$-loaded $\mathrm{TiO}_{2}$ paste in the squeegee process. The thickness of $3.0 \%$ Au-loaded $\mathrm{TiO}_{2}$ films was increased with increasing the concentration of Au-loaded $\mathrm{TiO}_{2}$ paste, as shown in Figure 7(a). Figure 7(b) shows the effect of 3.0\% Au-loaded $\mathrm{TiO}_{2}$ film thickness on short-circuit photocurrent properties of DSSCs. It was found that the short-circuit 


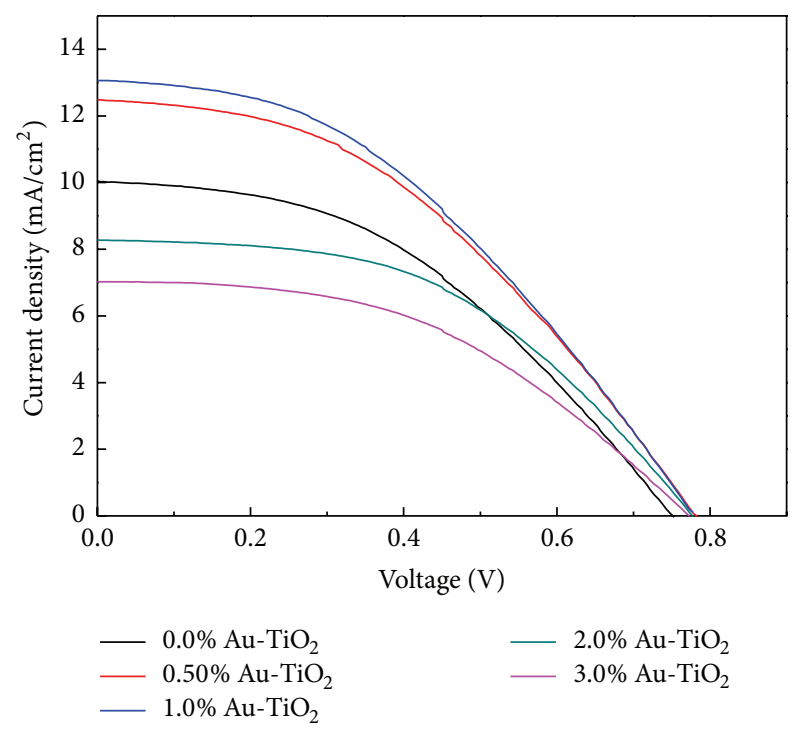

FIGURE 8: Current density versus voltage $(J-V)$ curves of fabricated DSSCs using $\mathrm{TiO}_{2}$ and $0.50-3.0 \mathrm{~mol} \%$ Au-loaded $\mathrm{TiO}_{2}$ nanoparticles.

TABLE 1: Photovoltaic performances of fabricated DSSCs using $\mathrm{TiO}_{2}$ and 0.50-3.0 mol\% Au-loaded $\mathrm{TiO}_{2}$ nanoparticles.

\begin{tabular}{lcccc}
\hline & $V_{\text {oc }}(\mathrm{V})$ & $J_{\text {sc }}\left(\mathrm{mA} / \mathrm{cm}^{2}\right)$ & $\eta(\%)$ & FF \\
\hline $\mathrm{TiO}_{2}$ & 0.75 & 10.04 & 4.34 & 0.43 \\
$0.50 \mathrm{~mol} \% \mathrm{Au}-\mathrm{TiO}_{2}$ & 0.78 & 12.48 & 5.40 & 0.42 \\
$1.0 \mathrm{~mol} \% \mathrm{Au}-\mathrm{TiO}_{2}$ & 0.78 & 13.06 & 5.52 & 0.44 \\
$2.0 \mathrm{~mol} \% \mathrm{Au}-\mathrm{TiO}_{2}$ & 0.77 & 8.27 & 4.13 & 0.56 \\
$3.0 \mathrm{~mol} \% \mathrm{Au}-\mathrm{TiO}_{2}$ & 0.77 & 7.02 & 3.33 & 0.39 \\
\hline
\end{tabular}

photocurrent increased with increasing film thickness up to $8 \mu \mathrm{m}$ (Figure 7(c)). However, the photocurrent decreased with the film thickness more than $8 \mu \mathrm{m}$.

3.3. Photovoltaic Properties of the Fabricated DSSCs Using $\mathrm{TiO}_{2}$ and $\mathrm{Au}$-Loaded $\mathrm{TiO}_{2}$ Nanoparticles. Photovoltaic properties of the fabricated DSSCs using $\mathrm{TiO}_{2}$ and different nominal $0.50-3.0 \mathrm{~mol} \%$ of $\mathrm{Au}$-loaded $\mathrm{TiO}_{2}$ nanoparticles were studied to compare the enhancement of photovoltaic performance of DSSCs. Figure 8 shows current density versus voltage $(J-V)$ curves of fabricated DSSCs using $\mathrm{TiO}_{2}$ and 0.50-3.0 mol\% Au-loaded $\mathrm{TiO}_{2}$ nanoparticles. Photovoltaic performances were calculated from these $J-V$ curves as shown in Table 1 . The open circuit voltage $\left(V_{\text {oc }}\right)$ is almost constant value with Au-loading amount. This indicates that the Au-loading to $\mathrm{TiO}_{2}$ does not affect the Fermi level because the $V_{\text {oc }}$ is originated from the energy difference between Fermi level of $\mathrm{TiO}_{2}$ layer and the oxidation/reduction potential of the electrolyte [44]. The results show that the short-circuit current densities $\left(J_{\mathrm{sc}}\right)$ of the fabricated DSSCs with $\mathrm{TiO}_{2}$, $0.50,1.0,2.0$, and $3.0 \mathrm{~mol} \% \mathrm{Au}$-loaded $\mathrm{TiO}_{2}$ nanoparticles were $10.04,12.48,13.06,8.27$, and $7.02 \mathrm{~mA} / \mathrm{cm}^{2}$, corresponding to the efficiency $(\eta)$ of $4.34,5.40,5.52,4.13$, and $3.33 \%$, respectively. These results confirmed that Au-loading could enhance the performances of DSSCs with the loading amount up to $1.0 \mathrm{~mol} \%$. However, the short-circuit current density and the efficiency of the fabricated DSSCs were decreased upon the increasing amount of $2.0 \mathrm{~mol} \% \mathrm{Au}$ loading. These effects might be possibly due to the fact that the active site was shielded by the large amount of Au loading or rougher morphology of the $\mathrm{Au}$-loaded $\mathrm{TiO}_{2}$ layers.

\section{Conclusion}

In this research, the Au-loaded $\mathrm{TiO}_{2}$ nanoparticles were successfully synthesized by the modified sol-gel method together with the impregnation method. Anatase phase of $\mathrm{TiO}_{2}$ was obtained in all samples with an average particle size of $20 \mathrm{~nm}$. The DSSC was improved by an effect of the Au-loaded titanium dioxide $\left(\mathrm{Au}\right.$-loaded $\left.\mathrm{TiO}_{2}\right)$. For the enhancement of DSSCs, the fabricated cell with up to $1.0 \mathrm{~mol} \% \mathrm{Au}$-loaded $\mathrm{TiO}_{2}$ could enhance the performance by localized surface plasmon effect and scattering property.

\section{Conflict of Interests}

The authors declare that there is no conflict of interests regarding the publication of this paper.

\section{Acknowledgments}

This research was supported by a Grant-in-Aid for Young Scientists (B) (23760010) and Grant-in-Aid for Scientific Research (C) (25390051) from the Japan Society for the Promotion of Science (JSPS), the Thailand Research Fund, The Royal Golden Jubilee Ph.D. Program (PHD/0358/2551), the National Science and Technology Department Agency (NSTDA), Thailand Graduate Institute of Science and Technology (TGIST: TG-55-10-52-051 M), the National Nanotechnology Center (NANOTEC), NSTDA, Ministry of Science and Technology, through its program of Center of Excellence Network, Thailand, and the Department of Chemistry, Faculty of Science, Chiang Mai University, Chiang Mai, Thailand. Sukon Phanichphant wishes to thank the National Research University Project under Thailand's Office of the Higher Education Commission for financial support.

\section{References}

[1] A. Fujishima, T. N. Rao, and D. A. Tryk, "Titanium dioxide photocatalysis," Journal of Photochemistry and Photobiology C, vol. 1, no. 1, pp. 1-21, 2000.

[2] K. Pirkanniemi and M. Sillanpää, "Heterogeneous water phase catalysis as an environmental application: a review," Chemosphere, vol. 48, no. 10, pp. 1047-1060, 2002.

[3] Y. Hu, H.-L. Tsai, and C.-L. Huang, "Effect of brookite phase on the anatase-rutile transition in titania nanoparticles," Journal of the European Ceramic Society, vol. 23, no. 5, pp. 691-696, 2003.

[4] V. Samuel, R. Pasricha, and V. Ravi, "Synthesis of nanocrystalline rutile," Ceramics International, vol. 31, no. 4, pp. 555-557, 2005. 
[5] O. Carp, C. L. Huisman, and A. Reller, "Photoinduced reactivity of titanium dioxide," Progress in Solid State Chemistry, vol. 32, no. 1-2, pp. 33-177, 2004.

[6] K. G. Deepa, P. Lekha, and S. Sindhu, "Efficiency enhancement in DSSC using metal nanoparticles: A Size Dependent Study," Solar Energy, vol. 86, no. 1, pp. 326-330, 2012.

[7] H. A. Atwater and A. Polman, "Plasmonics for improved photovoltaic devices," Nature Materials, vol. 9, no. 3, pp. 205213, 2010 .

[8] V. E. Ferry, J. N. Munday, and H. A. Atwater, "Design considerations for plasmonic photovoltaics," Advanced Materials, vol. 22, no. 43, pp. 4794-4808, 2010.

[9] S. Muduli, O. Game, V. Dhas et al., " $\mathrm{TiO}_{2}-\mathrm{Au}$ plasmonic nanocomposite for enhanced dye-sensitized solar cell (DSSC) performance," Solar Energy, vol. 86, no. 5, pp. 1428-1434, 2012.

[10] G. Sahu, S. W. Gordon, and M. A. Tarr, "Synthesis and application of core-shell $\mathrm{Au}-\mathrm{TiO}_{2}$ nanowire photoanode materials for dye sensitized solar cells," RSC Advances, vol. 2, no. 2, pp. 573$582,2012$.

[11] J. H. Lee and Y. S. Yang, "Effect of $\mathrm{HCl}$ concentration and reaction time on the change in the crystalline state of $\mathrm{TiO}_{2}$ prepared from aqueous $\mathrm{TiCl}_{4}$ solution by precipitation," Journal of the European Ceramic Society, vol. 25, no. 16, pp. 3573-3578, 2005.

[12] A. Sandoval, A. Aguilar, C. Louis, A. Traverse, and R. Zanella, "Bimetallic $\mathrm{Au}-\mathrm{Ag} / \mathrm{TiO}_{2}$ catalyst prepared by deposition- precipitation: high activity and stability in CO oxidation," Journal of Catalysis, vol. 281, no. 1, pp. 40-49, 2011.

[13] H. Wang, P. Liu, X. Cheng, A. Shui, and L. Zeng, "Effect of surfactants on synthesis of $\mathrm{TiO}_{2}$ nano-particles by homogeneous precipitation method," Powder Technology, vol. 188, no. 1, pp. 52-54, 2008.

[14] S. S. Kalanur, S. H. Lee, Y. J. Hwang, and O. S. Joo, "Enhanced photoanode properties of CdS nanoparticle sensitized $\mathrm{TiO}_{2}$ nanotube arrays by solvothermal synthesis," Journal of Photochemistry and Photobiology A: Chemistry, vol. 259, pp. 1-9, 2013.

[15] M. Kang, S.-Y. Lee, C.-H. Chung et al., "Characterization of a $\mathrm{TiO}_{2}$ photocatalyst synthesized by the solvothermal method and its catalytic performance for $\mathrm{CHCl}_{3}$ decomposition," Journal of Photochemistry and Photobiology A: Chemistry, vol. 144, no. 2-3, pp. 185-191, 2001.

[16] Y. Lee, J. Chae, and M. Kang, "Comparison of the photovoltaic efficiency on DSSC for nanometer sized $\mathrm{TiO}_{2}$ using a conventional sol-gel and solvothermal methods," Journal of Industrial and Engineering Chemistry, vol. 16, no. 4, pp. 609-614, 2010.

[17] Y. Zhang, H. Zheng, G. Liu, and V. Battaglia, "Synthesis and electrochemical studies of a layered spheric $\mathrm{TiO}_{2}$ through low temperature solvothermal method," Electrochimica Acta, vol. 54, no. 16, pp. 4079-4083, 2009.

[18] D. Crişan, N. Drăgan, M. Rǎileanu et al., "Structural study of solgel $\mathrm{Au} / \mathrm{TiO}_{2}$ films from nanopowders," Applied Surface Science, vol. 257, no. 9, pp. 4227-4231, 2011.

[19] J. N. Hart, D. Menzies, Y.-B. Cheng, G. P. Simon, and L. Spiccia, " $\mathrm{TiO}_{2}$ sol-gel blocking layers for dye-sensitized solar cells," Comptes Rendus Chimie, vol. 9, no. 5-6, pp. 622-626, 2006.

[20] M. Hočevar, U. O. Krašovec, M. Bokalič et al., "Sol-gel based $\mathrm{TiO}_{2}$ paste applied in screen-printed dye-sensitized solar cells and modules," Journal of Industrial and Engineering Chemistry, vol. 19, no. 5, pp. 1464-1469, 2013.
[21] C. M. Malengreaux, A. Timmermans, S. L. Pirard et al., "Optimized deposition of $\mathrm{TiO}_{2}$ thin films produced by a nonaqueous sol-gel method and quantification of their photocatalytic activity," Chemical Engineering Journal, vol. 195-196, pp. 347-358, 2012.

[22] S. Šegota, L. Ćurković, D. Ljubas, V. Svetličić, I. F. Houra, and N. Tomašić, "Synthesis, characterization and photocatalytic properties of sol-gel $\mathrm{TiO}_{2}$ films," Ceramics International, vol. 37, no. 4, pp. 1153-1160, 2011.

[23] H. M. N. Bandara, R. M. G. Rajapakse, K. Murakami, G. R. R. A. Kumara, and G. Anuradha Sepalage, "Dye-sensitized solar cell based on optically transparent $\mathrm{TiO}_{2}$ nanocrystalline electrode prepared by atomized spray pyrolysis technique," Electrochimica Acta, vol. 56, no. 25, pp. 9159-9161, 2011.

[24] C. Jiang, W. L. Koh, M. Y. Leung, W. Hong, Y. Li, and J. Zhang, "Influences of alcoholic solvents on spray pyrolysis deposition of $\mathrm{TiO}_{2}$ blocking layer films for solid-state dye-sensitized solar cells," Journal of Solid State Chemistry, vol. 198, pp. 197-202, 2013.

[25] C. Jiang, M. Y. Leung, W. L. Koh, and Y. Li, "Influences of deposition and post-annealing temperatures on properties of $\mathrm{TiO}_{2}$ blocking layer prepared by spray pyrolysis for solid-state dye-sensitized solar cells," Thin Solid Films, vol. 519, no. 22, pp. 7850-7854, 2011.

[26] M. Okuya, K. Nakade, and S. Kaneko, "Porous $\mathrm{TiO}_{2}$ thin films synthesized by a spray pyrolysis deposition (SPD) technique and their application to dye-sensitized solar cells," Solar Energy Materials and Solar Cells, vol. 70, no. 4, pp. 425-435, 2002.

[27] J. N. Hart, R. Cervini, Y.-B. Cheng, G. P. Simon, and L. Spiccia, "Formation of anatase $\mathrm{TiO}_{2}$ by microwave processing," Solar Energy Materials and Solar Cells, vol. 84, no. 1-4, pp. 135-143, 2004.

[28] J. N. Hart, D. Menzies, Y.-B. Cheng, G. P. Simon, and L. Spiccia, "A comparison of microwave and conventional heat treatments of nanocrystalline $\mathrm{TiO}_{2}$," Solar Energy Materials and Solar Cells, vol. 91, no. 1, pp. 6-16, 2007.

[29] S. Uchida, M. Tomiha, N. Masaki, A. Miyazawa, and H. Takizawa, "Preparation of $\mathrm{TiO}_{2}$ nanocrystalline electrode for dye-sensitized solar cells by $28 \mathrm{GHz}$ microwave irradiation," Solar Energy Materials and Solar Cells, vol. 81, no. 1, pp. 135-139, 2004.

[30] N. Wetchakun, B. Incessungvorn, K. Wetchakun, and S. Phanichphant, "Influence of calcination temperature on anatase to rutile phase transformation in $\mathrm{TiO}_{2}$ nanoparticles synthesized by the modified sol-gel method," Materials Letters, vol. 82, pp. 195-198, 2012.

[31] N. Wetchakun and S. Phanichphant, "Effect of temperature on the degree of anatase-rutile transformation in titanium dioxide nanoparticles synthesized by the modified sol-gel method," Current Applied Physics, vol. 8, no. 3-4, pp. 343-346, 2008.

[32] C. Suresh, V. Biju, P. Mukundan, and K. G. K. Warrier, "Anatase to rutile transformation in sol-gel titania by modification of precursor," Polyhedron, vol. 17, no. 18, pp. 3131-3135, 1998.

[33] Q. Zhang, L. Gao, and J. Guo, "Effect of hydrolysis conditions on morphology and crystallization of nanosized $\mathrm{TiO}_{2}$ powder," Journal of the European Ceramic Society, vol. 20, no. 12, pp. 21532158, 2000.

[34] T. Sugimoto and X. Zhou, "Synthesis of uniform anatase $\mathrm{TiO}_{2}$ nanoparticles by the gel-sol method. 2. Adsorption of $\mathrm{OH}$ ions to $\mathrm{Ti}(\mathrm{OH})_{4}$ gel and $\mathrm{TiO}_{2}$ particles," Journal of Colloid and Interface Science, vol. 252, no. 2, pp. 347-353, 2002. 
[35] D. Bahnemann, "Photocatalytic water treatment: solar energy applications," Solar Energy, vol. 77, no. 5, pp. 445-459, 2004.

[36] M. Harada, T. Sasaki, Y. Ebina, and M. Watanabe, "Preparation and characterizations of $\mathrm{Fe}$ - or $\mathrm{Ni}$-substituted titania nanosheets as photocatalysts," Journal of Photochemistry and Photobiology A: Chemistry, vol. 148, no. 1-3, pp. 273-276, 2002.

[37] M. Romero, J. Blanco, B. Sánchez et al., "Solar photocatalytic degradation of water and air pollutants: challenges and perspectives," Solar Energy, vol. 66, no. 2, pp. 169-182, 1999.

[38] M. Pan, N. Huang, X. Zhao, J. Fu, and X. Zhong, "Enhanced efficiency of dye-sensitized solar cell by high surface area anatase- $\mathrm{TiO}_{2}$-modified P25 paste," Journal of Nanomaterials, vol. 2013, pp. 1-6, 2013.

[39] G. Dai, L. Zhao, S. Wang et al., "Double-layer composite film based on sponge-like $\mathrm{TiO}_{2}$ and P25 as photoelectrode for enhanced efficiency in dye-sensitized solar cells," Journal of Alloys and Compounds, vol. 539, pp. 264-270, 2012.

[40] V. Dhas, S. Muduli, S. Agarkar et al., "Enhanced DSSC performance with high surface area thin anatase $\mathrm{TiO}_{2}$ nanoleaves," Solar Energy, vol. 85, no. 6, pp. 1213-1219, 2011.

[41] I.-K. Ding, J. Zhu, W. Cai et al., "Plasmonic Dye-sensitized solar cells," Advanced Energy Materials, vol. 1, no. 1, pp. 52-57, 2011.

[42] C.-Y. Huang, Y.-C. Hsu, J.-G. Chen, V. Suryanarayanan, K.-M. Lee, and K.-C. Ho, "The effects of hydrothermal temperature and thickness of $\mathrm{TiO}_{2}$ film on the performance of a dyesensitized solar cell," Solar Energy Materials and Solar Cells, vol. 90, no. 15, pp. 2391-2397, 2006.

[43] M. C. Kao, H. Z. Chen, S. L. Young, C. Y. Kung, and C. C. Lin, "The effects of the thickness of $\mathrm{TiO}_{2}$ films on the performance of dye-sensitized solar cells," Thin Solid Films, vol. 517, no. 17, pp. 5096-5099, 2009.

[44] M. Ghaffari, M. B. Cosar, H. I. Yavuz, M. Ozenbas, and A. K. Okyay, "Effect of Au nano-particles on $\mathrm{TiO}_{2}$ nanorod electrode in dye-sensitized solar cells," Electrochimica Acta, vol. 76, pp. 446-452, 2012. 

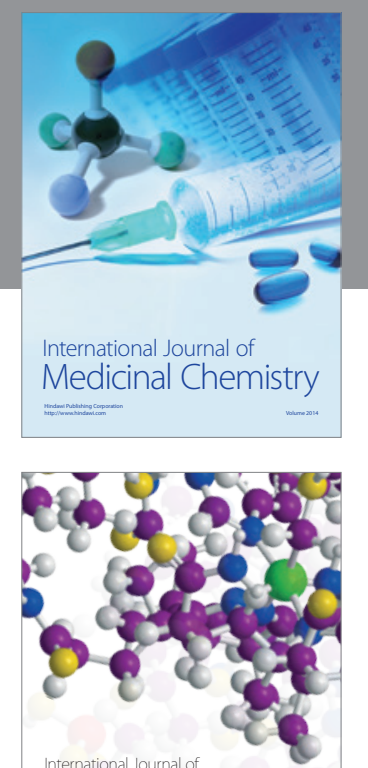

\section{Carbohydrate} Chemistry

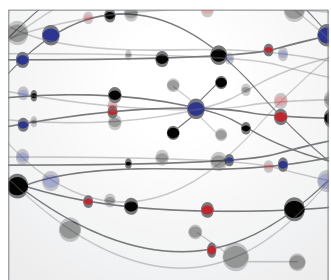

The Scientific World Journal
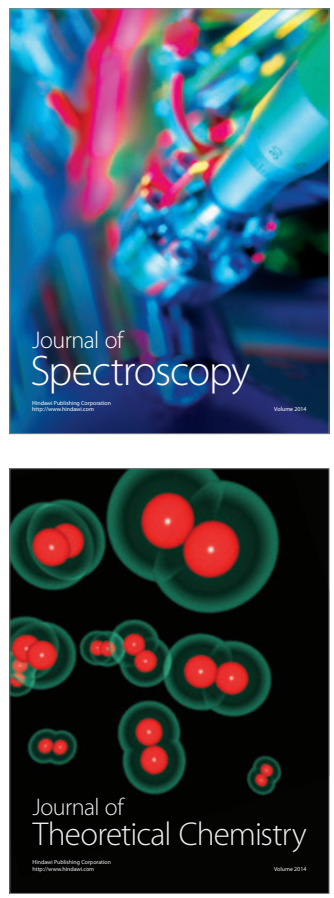
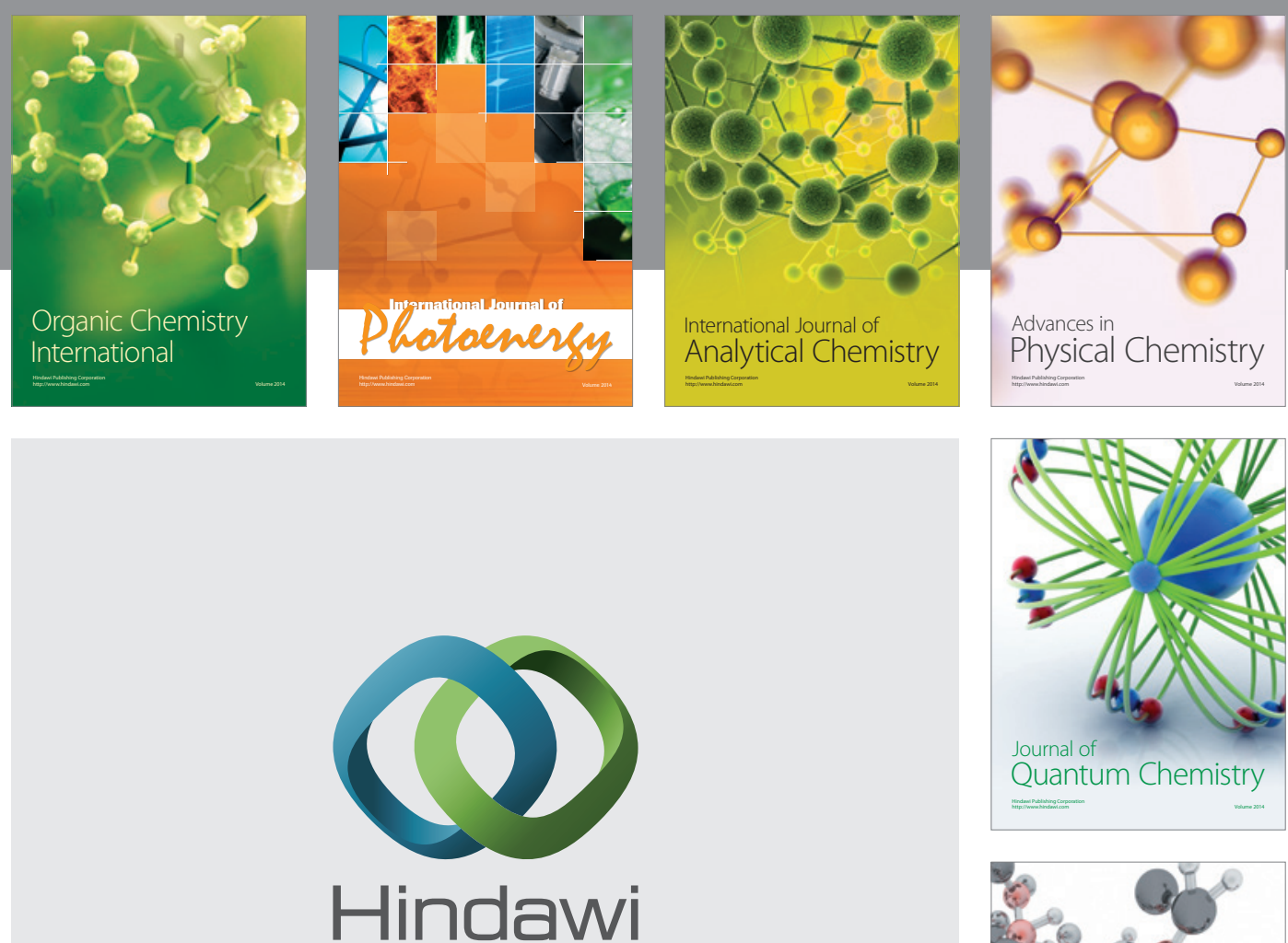

Submit your manuscripts at

http://www.hindawi.com

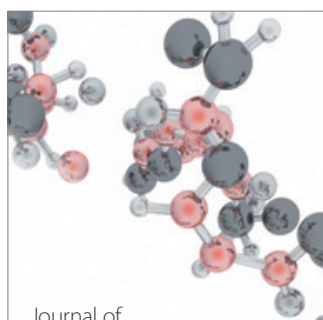

Analytical Methods

in Chemistry

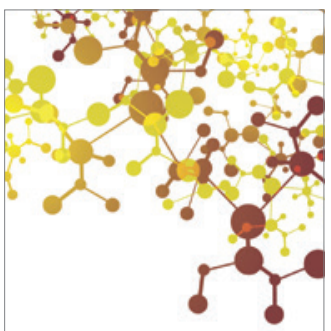

Journal of

Applied Chemistry

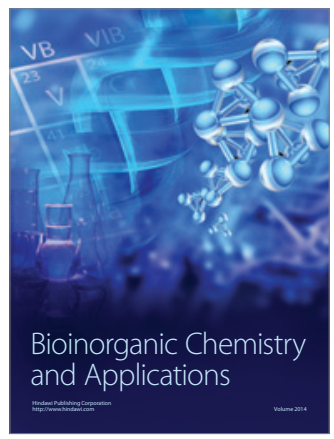

Inorganic Chemistry
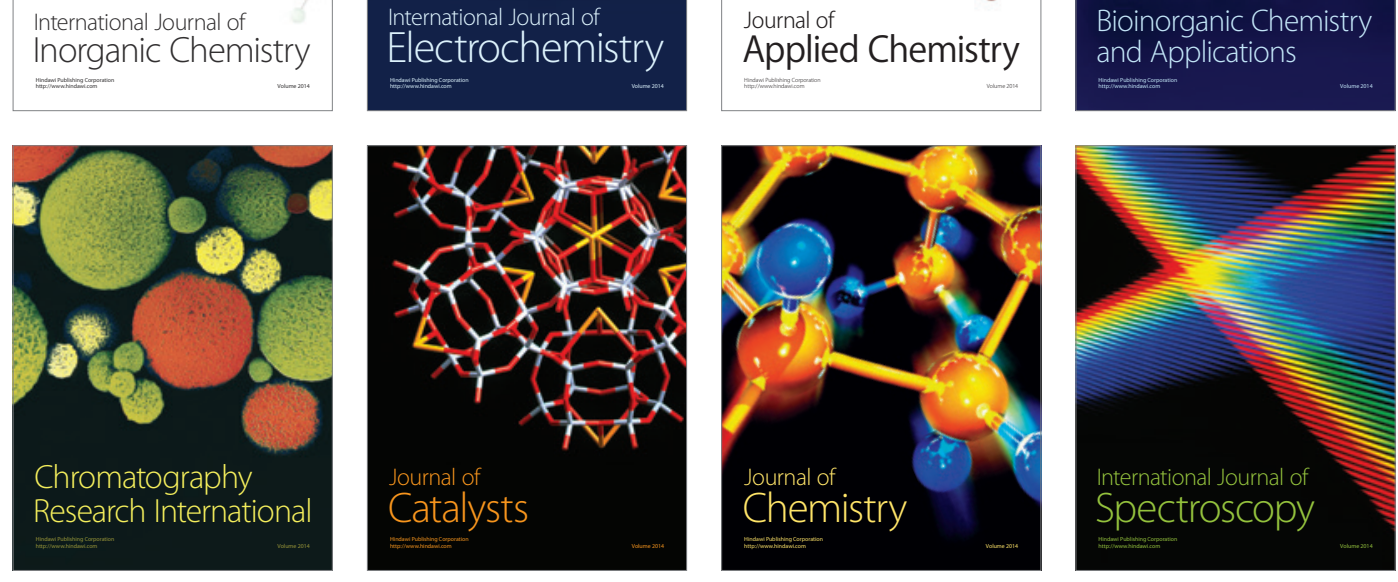